(www.danielkalla.com). One recent blog entry explains how he manages his time.

My advantage is my drive. When I sink my teeth into something, I do so with singlemindedness that borders on obsession. Other obligations and commitments invariably suffer, but I try to follow one rule that I won't let my wife or kids bear the brunt of my obsession. Family still comes first. However, when I'm writing a new novel, I cut back on all other pastimes. Netflix loses an avid follower. My timing in tennis goes to crap. I even stop reading for pleasure and focus solely on research.

Kalla says he is not as alarmist about pandemics in real life as he is in his books. Yes, a deadly crisis like the Spanish flu in 1918 could return and kill thousands, but those are rare occurrences. Kalla's fears for humanity are more exemplified by his second book, Resistance, in which a deadly bacterium is immune to all antibiotics. ("The kind of magnetic story you can't put down," declared Vancouver newspaper The Province.)

"The issue of the story - antibiotic resistance - still terrifies me," says Kalla. "I still think there will come a time when antibiotics won't work anymore. From my perspective, if I had to choose the one great threat, I would choose that."
But Kalla is not obsessing about plagues these days, not with a third Shanghai story to complete. "There are not many upbeat Holocaust stories, but this is one," says Kalla. Ninety percent of Shanghai's Jewish refugees survived. Their odds for survival exceeded those of Jews who remained in Europe. Maybe someone like the fictional Dr. Franz Adler improved those odds by his handling of life-and-death ethical dilemmas.

Paul Gessell

Art critic

Chelsea, Que.

CMAJ 2014. DOI:10.1503/cmaj.131413

\title{
The dude abides
}

\author{
Dude, Where's My Stethoscope? \\ and Other Stories from the ER \\ Donovan Gray \\ Elysium Books, 2012.
}

$\mathrm{H}$ ow hilarious is medicine? It's hard to say for certain. As a medical student, I learned how easy it was to become overwhelmed by the absurdity of a situation and default to amusement. "Gee, these suction cups that are supposed to hold ECG leads to a patient's chest make an odd little noise when they keep popping off." It's pretty funny at $3 \mathrm{am}$. Except that it's also frustrating and frightening and probably not at all funny for the patient.

The truth, which Dr. Donovan Gray acknowledges in this memoir, is that humour is often a defence against the anxiety and angst that arise in the practice of medicine. Gray has worked for many years in family practice and emergency medicine, and during that time he has collected a wide variety of experiences which he relates in over 90 short, interconnected essays as he

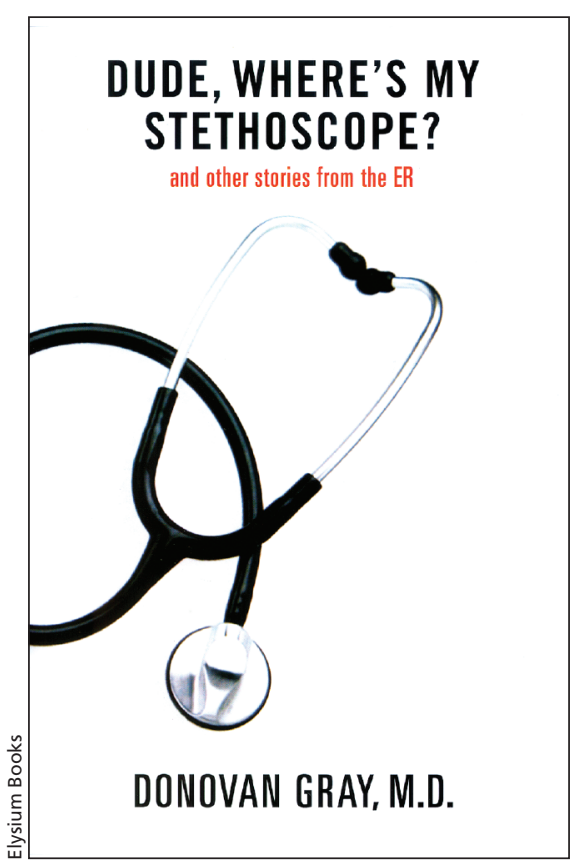

tells the story of his life in practice. Through the tales he tells, a picture emerges of what it means to practise in a busy emergency room in Canada, with all its unexpected frustrations and rewards.

I thought most of the anecdotes in the book were funny; very funny, in fact. One gets the impression that they are also true, which raises questions about confidentiality that every physician who writes about patients must address in some way. In Dude, Where's My Stethoscope, there is the additional complication that most of the time, the patients are the butt of the joke. As someone who has dabbled in medical humor writing, I find it is a fine line to walk between funny and making fun. At times, Gray is perilously close to crossing the line.

As I read Dude, I found myself wishing that Gray would apply his considerable talents as a writer to a more balanced style that incorporates humour into a nuanced and reflective narrative. While many physicians will find this an amusing book, I feel that there is so much more that we could learn from his experiences if we weren't so quick to laugh them off.

\section{Lara Hazelton MD}

Psychiatrist

Halifax, NS

CMAJ 2014. DOI:10.1503/cmaj.130867 